\title{
ASSESSMENT OF ECOLOGICAL DAMAGE FROM THE NATO BOMBING OF THE REPUBLIC OF SERBIA IN 1999
}

\author{
Saša T. Bakrač \\ Serbian Armed Forces, Military Geographical Institute \\ Emilija Klem \\ Ministry of Defence, Republic of Serbia \\ Miško Milanović \\ University of Belgrade, Faculty of Geography
}

In 1999, NATO bombed the Republic of Serbia, which inflicted

irreparable environmental damage on ecosystems and habitats. The topic of this paper is the method of determining and analyzing the assessment of inflicted ecological damage. Its quantification is possible, but it requires an integrated approach, since the exact value can be estimated only on a case-by-case basis. The financial valorization of environmental damage is an open and complex issue and it implies moral and ethical parameters.

The paper presents in general the assessment of ecological damage, and also the assessment of the damage inflicted on endemic and other types of habitats and ecosystems. A special emphasis is paid on the environmental damage assessment and the assessment of human health consequences that have arisen from the use of munitions with depleted uranium.

The problem of determining ecological damage and its consequences for ecosystems, habitats and humans due to the NATO bombing of Serbia in 1999 is particularly pointed out.

Key Words: environment, environmental damage, ecological consequences, depleted uranium, human health

\section{Introduction}

$T$ he ecological damage to biodiversity, caused in particular by the NATO bombing, is generally irreparable, and the losses inflicted on rare and endemic species are non-renewable. It should be said that industrial and other facilities of high ecological risk were destroyed in a deliberate and planned manner, which had an immediate negative ecological effect, primarily from aerial contamination. In rural and other less populated areas, the main impact of negative ecological effects of the war was seen on the developed vegetative cover, forests and other plants, aquatic ecosystems and soil, so that the immediate negative effect on humans was mitigated. However, the delayed 
negative effect increased through the food chain and bioaccumulation of toxic and carcinogenic substances. The bombing period coincided with the period in the reproductive cycle of most plants and animal species, which contributed to the increase in negative ecological effects. Since this was the period of return of migratory birds from the south, natural migratory birds routes were threatened. The migration of large game (bear, deer, wild boar, etc.) has been recorded, and presumably the migration of some rare species of birds (griffon vulture, eastern imperial eagle, etc.).

\section{Assessment of ecological damage}

Irreparable ecological losses are inflicted on nature by warfare. Fertile land is destroyed, forests, meadows and water disappear, as well as numerous species of flora and fauna. A special problem is a man's and human population health, that is, the increase in the risk to human health (Bakrač, 2017).

Ecological or environmental damage arises from ecological values, i.e. from the results of assessment of natural resources, from the evaluation of the most widely understood social and economic resources from nature (World Bank, 2011).

Major ecological damage may affect:

- human health,

- plants and animals,

- global ecological balance,

- natural and cultural resources,

- economic goods.

Ecological damage is an indicator that points to the integrated value of consequences, since the exact ecological damage can be estimated only on a case-by-case basis. Indicators that are most often used to determine ecological damage are the following:

- assessment of the hazard for organisms,

- assessment of the usefulness of the measure,

- remains in underground and surface waters, in soil and on plants,

- impact on biodiversity,

- amount of consumption and

- application conditions.

The assessment of ecological damage is the research of the scope of the danger that the possible state of the environment contains.

In order to assess ecological damage, it is necessary to create a database of quantitative indicators that are comparable, which is a prerequisite for establishing a value system. The possibility to include quantitative indicators is enabled by the market system. There is no assessment of ecological damage without determining their source and scope (Aleksić, 2012).

The scope of ecological damage is expressed by quantitative indicators, real or value, or qualitative, comparative ones. In doing so, one should start with the following criteria for identifying:

- type, quantity or characteristics of emissions from a particular source;

- type, quantity or characteristics of emission of produced or disposed waste; 
Assessment of Ecological Damage from the NATO Bombing of the Republic of Serbia in 1999

- contents of substances harmful to the environment: in raw material, semi-finished product or product;

- the scope of ecological damage that can be determined after an appropriate ecological analysis that includes:

- pollution cadastre - identification of sources of pollution and its levels,

- identification of changes in the environment that arose as a result of pollution,

- determination of the scope of the impact of environmental changes on economy, the quality of life and work,

- calculation of environmental costs.

\begin{tabular}{|c|c|}
\hline & $\begin{array}{l}\text { rmula for assessment of ecological damage to habitat } \\
\text { ED = UP CORINE * CCPA * CISPNG * CPDR * SD }\end{array}$ \\
\hline $\begin{array}{l}\text { ED - } \\
\text { UP CORINE - }\end{array}$ & $\begin{array}{l}\text { ecological (biological) damage } \\
\text { unique price according to the CORINE habitat classification } \\
\text { system per } 1 \text { ha of space }\end{array}$ \\
\hline $\begin{array}{l}\text { CCPA - } \\
\text { CISPNG - } \\
\text { CPDR - } \\
\text { SD - }\end{array}$ & $\begin{array}{l}\text { coefficient by category of protected area } \\
\text { coefficient of the international status of protected natural goods } \\
\text { coefficient of protection degree regime } \\
\text { surface of damage }\end{array}$ \\
\hline
\end{tabular}

Determining the source and degree of emission of pollutants, duration and spatial impact, the display of changes in the middle are shown using the scale. Comparisons include pollution of water, air, plants and the functioning of ecosystems. The scope of ecological damage is expressed by quantitative and qualitative indicators.

In many countries, before making a decision on the environmental impact, the Environmental Impact Study is mandatory. This study is believed to be a natural method of ecological damage assessment. This includes a detailed description of environmental impact, alternative solutions, unavoidable impact, resource use/pollution analysis, environmental evaluation and impact assessment with protection measures.

In order to introduce the economic evaluation of the environment, the same principles as when evaluating the products of human work should be followed. These are the "principle of willingness to pay" (WTP) and the "principle of willingness to accept compensation" (WTA) for ecological damage or environmental degradation. When these parameters can be measured, then economic evaluation allows ecological damage and benefits to be expressed financially. For example, in order to determine the value of different pollution control scenarios, there is also the possibility of assessing ecological net benefits and damage to society as a whole (Aleksić, 2012).

The financial valorization of ecological damage is an extremely complex issue that includes moral and ethical norms. Problems in the assessment of ecological damage arise mainly from the very nature of flora and fauna. Direct damage to flora and vegetation is relatively easy to assess whereas the problem with animals is much greater. Damage to flora and fauna, as well as habitats, is much more difficult to notice in 
the field and prove exactly. It is therefore acceptable to determine the damage on representative samples. Much damage is latent, long-term and can be recorded only in the offspring (World Bank, 2011)

Research on war damage from the NATO bombing done in 1999 to the diversity of bird fauna in Serbia has shown that they are neither small nor negligible. Over 1,000 bombarded sites and facilities were registered in Serbia at that time (Federal Ministry of Development, Science and Environment, 2000). Estimates say that the number of dead birds or those who did not breed due to war destruction is up to 100,000 birds within 120 species. When this number gets a monetary expression through the existing damage price list, the damage to bird fauna has been roughly estimated to be 10-20 million dollars. Evaluation data refer to around $30 \%$ of the total familiar species diversity of bird fauna in Serbia, and other bird species that otherwise, by air, water, or soil were subjected to some sort of negative impact. The assessment of ecological (biological) war damage on the biodiversity of Serbia is possible using a unique formula and price list. This is done on the basis of the unique price according to the CORINE classification system, the coefficient depending on the category of protected area, the coefficient of the international status of protected natural goods, the coefficient depending on the natural goods protection regime and the surface of the damage. The estimated damage according to this model amounts to US $\$ 3,130,427,166$ (Federal Ministry for Development, Science and Environment, 2000).

The main sources of ecological pollution caused by bombing are:

- industrial and other facilities of high ecological risk that have been hit,

- direct action of the military forces through three different ecological aspects:

- impact of aviation motors and cruise missiles on nature,

- impact of special ammunition (especially depleted uranium missiles),

- action of defensive land forces.

\section{Assessment of ecological damage inflicted on endemic and other species}

Warfare results in significant ecological damage in areas where there are the only habitats and population of endemic endangered species. Since the bombardment included $75 \%$ of the total territory of Serbia, it can be concluded that there have been negative changes in the habitat of almost all endemic species and the negative trend of their population can be expected. For example, a monotypic species, hoverfly Cheilosia griseifacies terra typica, is known only from several sites in the Pannonian Basin and periphery. It is assumed that the entire population has suffered a change since the area of its habitat around Novi Sad was exposed to intense warfare for about 40 days.

It is considered that endangered species, whose part of the world population was located in Serbia, were exposed to intense warfare. Among them is the bee fly Cheilosia Clama Claussen \& Vujic, 1995, located on Kopaonik, as well as Pančić wormwood Artemisia pancicii, located only in Deliblato Sands, and it experienced warfare for about 50 days. This area was exposed to great air and soil pollution due to the destruction of Pančevo industrial plant. 


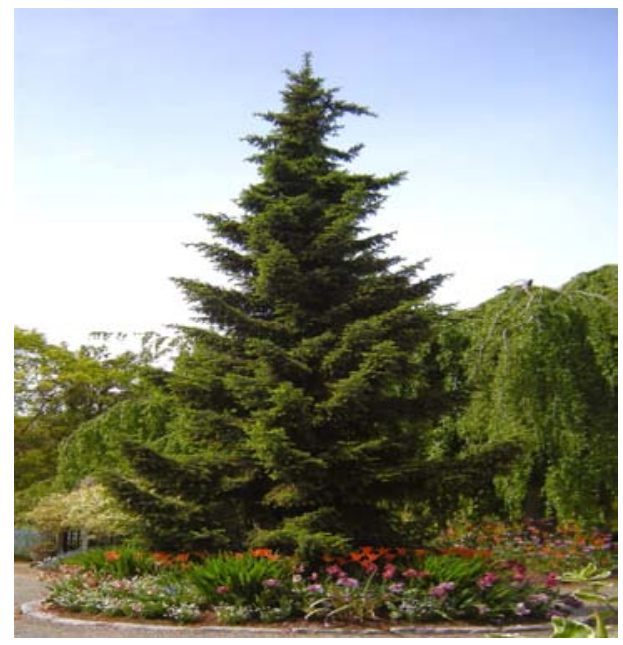

Picture 1 - Picea omorika Purkyne, Serbian spruce

Red lungwort Alkanna pulmonaria Griseb was found only on the border with FYR Macedonia. In addition to air strikes, its habitat was also exposed to land warfare.

Lutra lutea otter, the natural rarity of aquatic ecosystems, is an ichthyophagous species and it is located at the top of the aquatic ecosystem chain. It is estimated that the exposure to the 130-day attacks has resulted in at least $50 \%$ of the impact of the warfare.

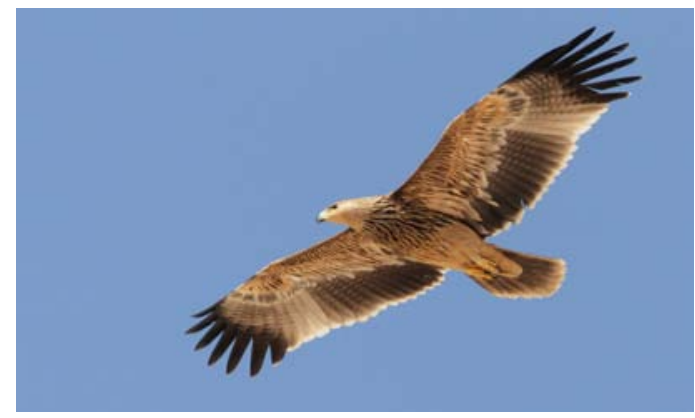

Picture 2 - Aquila heliaca, eastern imperial eagle eagle

The warfare took place during the breeding period of the globally endangered species of eastern imperial eagle Aquila heliaca.

Prickly saltwort Salicornia europaea $L$. is an indicator of sensitive halophilic ecosystems and changes in its population indicate changes in their sustainability.

The least horseshoe bats, Rhinolophus, feed insects and they can serve as indicators of the vitality of ecosystems. They were exposed to warfare for about 30 days. 


\section{Assessment of ecological damage inflicted on habitats and ecosystems}

Before the beginning of the bombing about 500 hectares of the territory of Serbia was protected or a procedure for protection of the area was initiated, which represents $17 \%$ of the total area. Some of these areas are known as biodiversity centers, and some of them are of international interest and importance. Since the warfare encompassed a large part of the territory of Serbia, the ecological damage inflicted on ecosystems rich in species can be assessed as serious and long-lasting (Damjanov, 2001).

The areas of amphibians and reptiles of high diversity (with over 30 species) suffered the greatest damage in the central and southern parts of Serbia, while the areas of middle diversity were the worst hit in the western Serbia. Areas of international and national significance for the conservation of birds have been exposed to warfare of varying intensity.

Sensitive ecosystems and areas where endemic species live are hardly sustainable even in peacetime conditions. An example of sensitive highland ecosystems, whose indicator is salamander, was exposed on Prokletije for less than 30 days. The exposure to warfare on the Šar Mountains was more than 30 days. Having in mind the small surface of these ecosystems, it is estimated that there have been significant changes in their vitality. With regard to the exposure to warfare, it is considered that over $50 \%$ of preserved aquatic ecosystems have undergone smaller or greater changes.

\section{Assessment of ecological damage caused by the use of munitions with depleted uranium}

The negative effects of depleted uranium in humans and other organisms result from alpha radiation and they carry a high risk by direct ingestion as an internal source of radiation. Radioactive contaminated soil when using munitions with depleted uranium includes room, whose boundaries are defined as follows:

a) when hitting the target with "hard" substrate, the boundary of radioactive contaminated land is, regardless of the direction of the ground wind, the circle with $100 \mathrm{~m}$ radius around the facility that has been hit, and the degree of radioactive contamination is greater than $0.5 \mu \mathrm{Gy} / \mathrm{h}$, which is measured at or within the facility that has been hit, the land in the immediate vicinity of the facility that has been hit or on the parts of the missile that have been found;

b) when hitting the target with "soft" substrate (earth), metal uranium in a small percentage goes into the phase of insoluble aerosols, which are deposited in the circle with $10-20 \mathrm{~cm}$ radius around the holes in the ground. Metal uranium will be found in the soil to a depth of about $1 \mathrm{~m}$, so it is possible to interact with water from underground and surface currents. The boundary of radioactive contaminated land is defined by the circle with $5 \mathrm{~m}$ radius, and the degree of radioactive contamination is greater than $0.5 \mu \mathrm{Gy} / \mathrm{h}$. 
The degree of radioactive contamination is measured within the hole in the ground, at 10-20 $\mathrm{cm}$ around the opening or on the bare part of the soil, which has been formed by a ricochet projectile. Radiologically contaminated atmosphere does not exist except in the cases of fire in the affected region. The total area of contaminated land is equal to the sum of individual contaminated surfaces. Radioactive contaminated atmosphere, when using munitions with depleted uranium includes space in the direction of wind blowing, in which aerosols of depleted uranium can be detected. The radioactive effect of depleted uranium can be caused by external or internal irradiation. External irradiation is significant, first and foremost in the cases when the whole core or part of it is found near humans.

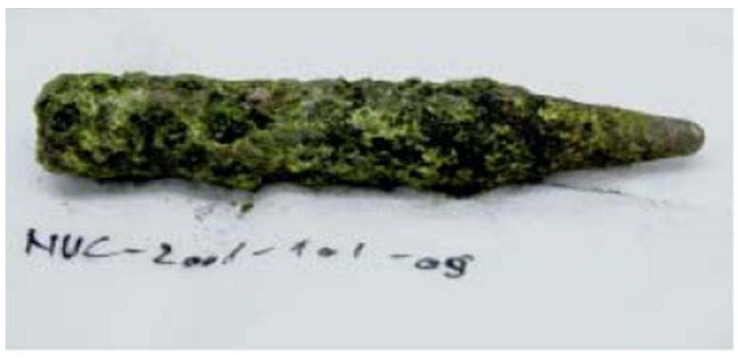

Picture 3 - Corroded penetrator found on Pljačkovica

Penetrators of depleted uranium, if they do not burst when hitting hard surface, strike at soft soil to a depth of one up to three meters. Then it is very difficult to detect them. Unfortunately, if they stay on the surface or strike at the ground, penetrators quickly corrode, uranium oxidizes and oxides that are soluble in water are formed. Thus depleted uranium can reach groundwater, and through them drinking water, as well. If different uranium compounds are inserted into the body via water or food, one part remains in the body and settles in bones, liver, kidneys, and it results in various illnesses. Uranium belongs to a group of heavy metals that are chemically highly toxic, and the insertion of relatively large amounts of uranium into the organism causes reactions similar to other chemical poisoning within a few hours after the insertion.

\section{Assessment of consequences (damage) to human health}

The consequences of the NATO bombing for human health can be considered from the aspect of all environmental problems that arose in the 1999 conflict (Bakrač, 2017). From pollution of water, air and soil, as well as noise, the exposure to depleted uranium is one of special and emphasized problems. Ten million citizens of Serbia were found in March, April and May 1999 in the zone of radiation risk, and they are still located in that zone (Čikarić, 2017). Uranium is considered not to be a physiological ingredient of organism and it should always be treated as a result of contamination. Depleted uranium contamination does not recognize the borders of bombarded areas. For example, the zone of exposure after bombing targets in the Persian Gulf and in the Balkans with depleted uranium missiles is 2,400 miles (Morett, 2006). 
During the explosion of a bomb containing depleted uranium, the temperature is 3,000 degrees Celsius. On that occasion, the release of micro and nano particles occurs. At a higher temperature, the particles are finer, allowing them greater penetrability.

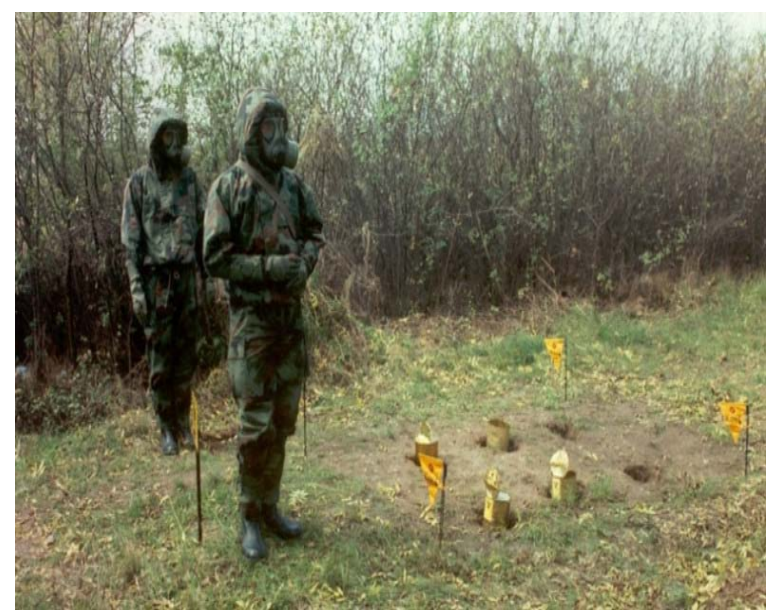

Picture 4 - Removal of munitions with depleted uranium

After the exposure to depleted uranium particles, the dominant way of human exposure is inhalation (Đurović, 2011). The assessment of the consequences of the NATO bombing for human health (Institute of Public Health of Belgrade, 1999) is virtually impossible to valorize. It can only be presented through several factors that have a direct or indirect effect on human health. This may be the occurrence of the following conditions:

- disorder of the central nervous system,

- increase in malignant diseases (cancer of the lungs, thyroid, ovaries and digestive organs) and leukemia,

- psychological problems,

- digestive disorders,

- disorders of the natural balance of the environment,

- disturbance of climate in limited areas and to a limited extent,

- destruction of flora and fauna,

- destruction of the ozone layer,

- pollution of air, soil, water and underground streams,

- genetic disorders,

- increase in sterility in both sexes.

Depleted uranium, as a carcinogenic substance, has a latent period for leukemia and lymphomas on average 7.5 years, while for solid tumors (cancer of the breast, cervix, lungs and colon) it is on average 15 years (Čikarić, 2017). This substance is most often deposited in the lungs, significant doses in the bronchial lymph nodes, and somewhat lower doses in the extratorous respiratory tract, lymph nodes, kidneys, liver 
and bones. There is the interaction between alpha particles and immune lung cells, which results in the formation of Lupus erytematodes (LE) cells. A ten-year research (1992-2002) of 225 samples of bronchoalveolar lavage of pediatric patients exposed to depleted uranium particles from the territory of central Serbia, Vojvodina, Bosnia and Herzegovina and Montenegro resulted in 47 positive LE samples found (Žunić, 2016). This indicated the In vivo Petkau effect, that is, the destructive effect of small, slow, repeated doses of depleted uranium a particles, bearing in mind the large exposure to depleted uranium nano particles that was repeated every four years (the Gulf War in 1991, the war in Bosnia and Herzegovina in 1995, the war in FR Yugoslavia in 1999 and the war in Iraq in 2003).

In order to provide the conditions for high-quality and efficient implementation of ionizing radiation protection measures and nuclear safety measures in carrying out radiation and nuclear activities, the Serbian Government established in 2009 the Serbian Radiation Protection and Nuclear Safety Agency as an independent regulatory organization that exercises public authorization in accordance with the law. There are reports of this Agency on radiation monitoring from 2010 to 2015.

In order to assess the environmental vulnerability and health risk for population, special attention is paid to the control of environmental radioactivity at the sites that were affected by the NATO bombing. The control included testing the content of radionuclides (radioactive atoms) in the samples of water, plants and soil. "The measured values of total alpha and total beta activities in the water samples are below the limits stipulated by the Rule book. The content of radionuclides gamma radiation emitters in the water samples is low and in most of the tested samples it is below the limits of detection. The content of radionuclides in the plants samples from locations where depleted uranium has been used corresponds to the content of radionuclides that is characteristic for plants from other locations in Serbia. The highest concentration of radionuclides in soil was measured in the samples from the Bratoselce site. Although the measured values are several times higher than the values measured in other locations, the isotope activity ratio confirms that uranium in the tested samples is of natural origin", it is written in the report of the Agency, which also provides tables of the measured values.

At the end of this document, the assessment of the vulnerability of the population is stated, i.e. the following is concluded: "According to the overall results of measuring the environmental radioactivity in the territory of the Republic of Serbia in the period 20112015 , it can be concluded that the activity of both natural radionuclides and long-lived radionuclides of artificial origin (mainly from Chernobyl precipitation) in different types of samples (air, precipitation) moved at low levels. On the basis of the value of the effective dose of manufactured radionuclides received by an average citizen of the Republic of Serbia in 2015 by ingestion (food intake) and inhalation (breathing) and which is less than $0.01 \mathrm{mSv}$, it can be concluded that the radiation risk for the population from manufactured radionuclides is negligible."

The data of the Public Health Institute in Vranje correspond to the findings of the Radiation Protection Agency. The number of malignant diseases patients does not increase any more, actually it slowly decreases. Thus, in 2009435 cases were reported, in contrast to 2005, when there were 758 cases (Table 1). 
Table 1 - Review of the ratio of the number of newly infected with malignant neoplasms (all locations) in the municipality of Vranje in the period 2000-2009.

(Source: Antić, 2010)

\begin{tabular}{|c|c|c|c|c|c|c|c|c|c|c|}
\hline Year & 2000 & 2001 & 2002 & 2003 & 2004 & 2005 & 2006 & 2007 & 2008 & 2009 \\
\hline $\begin{array}{c}\text { No. of } \\
\text { infected }\end{array}$ & 350 & 479 & 616 & 653 & 669 & 758 & 743 & 553 & 409 & 435 \\
\hline
\end{tabular}

It is believed that the number of infected with malignant diseases is directly linked to the bombing by munitions with depleted uranium. However, to date, there are no official reports on monitoring the health of soldiers and civilians in Serbia, who were exposed to the impact of depleted uranium during the bombing.

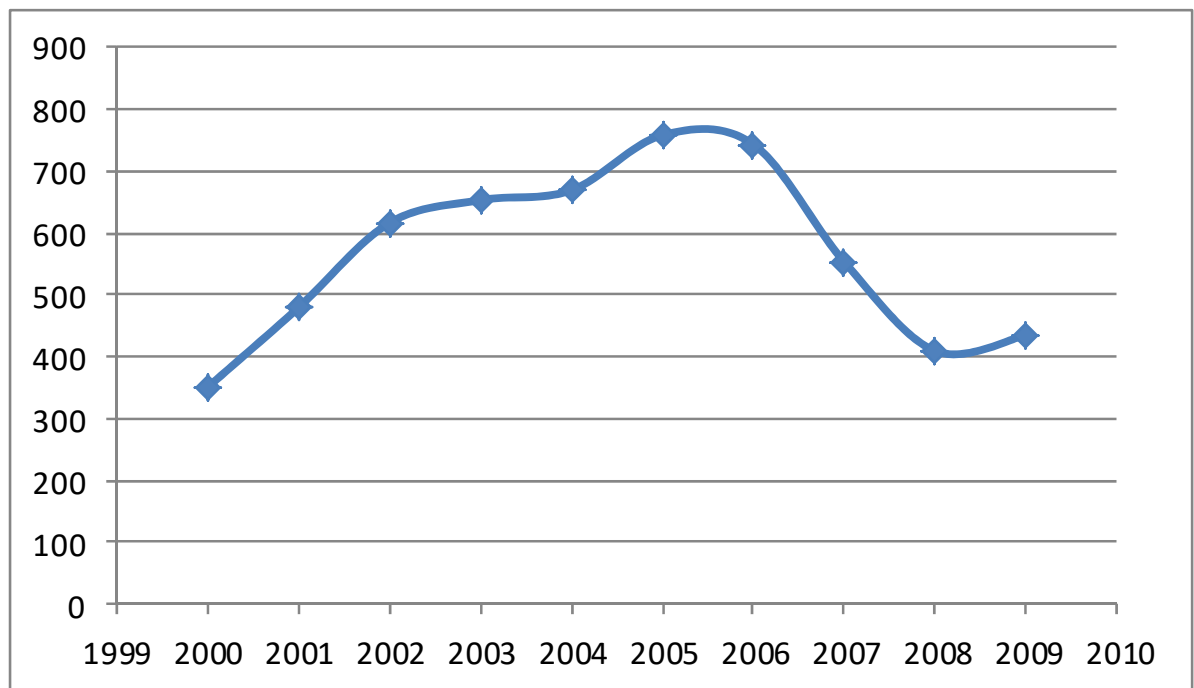

Picture 5 - Graph of the total number of newly infected with malignant neoplasms (all locations) in the municipality of Vranje in the period 2000-2009.

(Source: Antić, 2010)

\section{Conclusion}

During the NATO bombing of Serbia in 1999, flora and fauna, humans and ecosystems suffered great ecological damage. It is difficult to determine the extent of the inflicted ecological damage, and it is even more difficult to estimate it because it also implies moral and ethical norms. If it is known that damage is most often latent and longterm, this means that it can only be recorded by the offspring.

The bombing destroyed industrial and other facilities of high ecological risk. This had an immediate negative ecological effect meaning pollution of water, air and soil, as well as other physical and chemical damage. A special segment of the negative ecological effects of this 
Assessment of Ecological Damage from the NATO Bombing of the Republic of Serbia in 1999

warfare is related to the use of munitions with depleted uranium. It is believed that the use of this ammunition has led to enormous ecological consequences, causing great ecological damage and the risk to human health. Credible data are required for an objective and professional assessment of ecological damage. Thus, for damage caused by the use of depleted uranium missiles data on the number and type of projectiles, number of locations and areas that were hit, analytical data on uranium activity and its offspring in the environment (air, water, soil, plants, sediment, foods of plant and animal origin, food for livestock) are required. In addition, data on urine and blood of directly and indirectly exposed persons and certain hematological and cytogenetic parameters are also necessary.

So far, the expert public has presented and published various opinions and data on the scope and consequences of the NATO bombing. Taking into account the past time distance, the authors of this paper think that multidisciplinary scientific research should be conducted in order to determine inflicted ecological damage and assess the consequences of the bombing.

\section{References}

[1] Алексић, J., Драгосављевић, 3., Аџемовић, М. 2012. Методологија процене еколошке uтете. Београд: Факултет за примењену екологију Футура.

[2] Антић, Е., 2010. Анализа појединих показатеља здравственог стања становништва града врања у 2010. години са предлогом мера за његово побољшање, Завод за јавно здравље Врање, стр. 3.

[3] Бакрач, С. 2017. Процена ризика по човеково здравље, стање и перспективе у Р. Србији, Војно дело.

[4] Бакрач, С., Клем, Е., Милановић, М. 2017. Еколошке последице ратних дејстава, Војно делојесенОпштевојни научнотеоријски часопис.

[5] Дамјанов, В., Вукићевић, А., Грозданов,J. 2001. Effects of Nato airraids on human environment and health of the population of Serbia, Environmental recovery of Yugoslavia, стр. 357-365.

[6] Чикарић, С., 2017. За пораст броја умрлих и оболелих од рака кривац је осиромашени уранијум којим смо бомбардовани током Нато агресије, Нова српска политичка мисао, часопис за политичку теорију и друштвена истраживања, Београд.

[7] Ђуровић, Б., Спасић, В., Петовић, С., Фортуна, Д., Селаковић, В., Атлагић, Н. 2011. Осиромашени уранијум, методе детекције, санирање непосредних ефееката и превенција касних последица. Београд.

[8] Жунић, С., Ракић, Љ. 2016. Depleted Uranium Induced Petkau Effect - Challenges for the Future. Nova Science Publishers, Inc. New York USA.

[9] Institute of Public Health of Belgrade and Serbian Chemical Society, 1999, The environment and health consequence of NATO aggression on Yugoslavia, 17-th Conference, Belgrade, October.

[10] Moret. L. 2006. U.S. Weapons Poison Europe. Radiation from Iraq War detected in UK atmosphere. American free pres. net. Isue 10/11. Available at: ww.americanfreepress.net/html/weapons_poison_europe.html.

[11] Савезно министарство за развој, науку и животну средину, 2000. Последице НАТО бомбардовања на животну средину СР Југославије- Извештај, стр. 1-87.

[12] World Bank. 2011. Methodology for calculating environmental damage assessment and relevant compensation. Washington, DC: World Bank. http://documents.worldbank.org/curated/en/804831468331771041/Methodology-for-calculatingenvironmental-damage-assessment-and-relevant-compensation 